Caspian sea. This course of the Wolga from Kasan to Astrachan measures 225 geographical miles, and is only occasionally touched by the low-lying spurs or inferior ranges of the Ural mountains; whilst the plains between the towns of Samara and Ural to the north, and the Caspian to the south, are studded with salt lakes, marshes, and sands; vegetation is, nevertheless, abundant, and well sustains the splendid studs of mares which accompany the nomadic Tartar tribes.

The towns which have lately become more prominent in medical literature are Samara and Orenburg, and these are well described in Dr. Ucke's work, "Das Klima und die Krankheiten von Samara," Berlin, 1863. From this it is clear that Samara is but a few feet above the level of the sea, and that the Wolga yearly overflows the country on its right bank. Dr. O. de Maydell, Medical Inspector to the Russian Govermment in Orel (giving an account of six years' residence in Orenburg), and von Humboldt (passing through Orenburg with Ehrenberg and Gustave Rose) both state that Orenburg itself, notwithstanding its distance from the Caspian, lies below the level of the ocean. It is a curious and often-recorded fact that (as shown in Peterman's map of Russia in Europe) the Caspian is about eighty-five feet below the level of the Black sea, and that the Aral sea is 117 feet above the Caspian level, or thirtytwo feet above that of the Black. Further evidence will scarcely be needed to convince Mr. Cullimore that the 'Tartar steppes which have any interest for the medical world (those namely, known to possess immunity from consumption) are to be regarded, in respect to their elevation, as scarcely, if at all, above the level of the sea, in any part of their extent, whilst in some portions they are actually below such level.

With regard to Mr. Cullimore's scepticism on, as I think, the well-established absence of consumption in Ireland, his "difficulty of obtaining reliable information in such a remote and sparsely populated country," I would refer him to Dr. Arthur Leared'svaluable articles on the subject in the British Medical Journal during January, February, and March 1869 , as well as to that of his friend, Dr. Hjaltalin of Iceland (ibid., August 28th of the same year). Both writers have, in my judgment, sufficiently proved the fact that phthisis, when it does occur in Iceland, is never indigenous, but always imported from a foreign country. According to some authors (Samuel Hibbert, Horrebow, \&c.) the Shetland, Faroe, and Hebrides islands are, like Iceland, almost entirely exempt from consumption; and the late Dr. Edward Charlton, of Newcastle-upon-Tyne, states in a published pamphle that in Iceland and the Faroe islands phthisis is absolutely unknown, and that it was very rare in Shetland until the commencement of the present century.

In summing up these few considerations, on the hypothesis that consumption does not exist in the several countries which have been mentioned, how is such immunity to be accounted for? What is there in common in those countries likely to shield their inhabitants from this dreaded disease? Is there any agreement in the geographical position, the meteorology, the geology, the vegetation, the food, or even in the habits of the people? If such there be, it should be of the highest value in determining an interesting and most important question.

Speaking for myself, I have little belief in any exclusive influence of climate (whether upon high or low levels) upon phthisis, without a proper diet and medical treatment, either in preventing, arresting, or curing the disorder. Phthisis may, and does, arise from various causes, and, in assuming various forms, will, doubtless, require varied treatment; bu I am aware that hopes of suceess may now be indulged which could not justifiably exist at any previous period of medical history.

The Tartar steppes are known to be visited mostly in summer, when the air is hot and dry and patients can drink and perspire most freely; but visits are not paid for the sake of the climate, but for that of the renowned beverage of the country, which beverage is considered to be a specific antiphthisicum, and is consumed in the largest possible quanti ties. It is the belief of great numbers of medical men (as Drs. Ucke, Chomenkoff, Postnikoff, Maydell, Neftel, Schnepp, Stahlberg, \&c.) that if anything whatever can be found to check consumption, the beverage just referred to (koumiss) is that something, and especially in a climate like that of the Tartar steppes during the summer. The general results so attained have been marvellous, and such as to surpass the benefits which have been obtained either by high altitude or by any other mode of treatment. Excellent evidence has already been forthcoming on the subject, and much more could be furnished in response to any general inquiry.

Coincidently it happens that in Iceland, the Faroe, and Shetland isles the favourite drink is likewise a partially fermented liquor made from whey-the serum of milk, and Dr. Charlton says that " in proportion as this drink (called 'Bland') has fallen into desuetude in Shetland, where we often enjoyed it forty years ago, and been substituted by tea and coffee, so has phthisis increased." Thus it is clearly to be shown that if no other resemblance can be indicated between the regions to which I have referred, there is at least that of a like dietary, the importance of which my own not inconsiderable experience, both in Germany and in this country, does not lead me to underrate.

I am, Sir, your obedient servant,

V. A. JAGIELSKI, M.D., M.R.C.P.L., Whysician to the Infirmary for Consumption, \&c. Weymouth-street, Sept. 3rd, 1879

\section{A GALLANT ACT.}

To the Editor of THE LANCET.

SIR,-I have read with much pleasure of the gallant deeds done by many of England's brave sons at the battle of Kambula and elsewhere throughout the war now happily drawing to a close, but nowhere have I seen publicly mentioned an act which, for bravery and coolness, has not been surpassed by any other in this campaign. Though reported officially to the Medical Department, a considerable time mustelapse before it receives the recognition which it seems to deserve. Allow me, through the medium of your colnmns, to be the means of rescuing it from oblivion, in justice to two of my brother officers who already served with distinction in the Ashantee campaign.

During the hottest part of the action at Kambula, on the 29th March last, Private Daley, of the 90th L. I., who had sustained a severe wound of the upper arm, was carried to the Field Hospital ; he was bleeding profusely, and it was found necessary to amputate his arm immediately. This was successfully done, under a very hot fire, by Surgeon D. Thornton, assisted by Surgeon A. Lennon Brown, A.M.D.

It is needless to remark that, even under the most favourable circumstances, the performance of a surgical operation requires the greatest coolness and steadiness on the part of the operator and his assistants. The best proof that these officers possess such qualities in a marked degree lies in the fact of their having saved their patient's life under such very trying circumstances. I am happy to state the man made a good recovery. Had the operation been deferred until the termination of the action, the man would, in all human probability, be amongst his dead comrades of the 90th.

I am, Sir, your obedient servant, Charles McD. Cuffe,

Surgeon-Major, Senior Medical Officer, Wood's Column. Camp, Wood's Flying Column, Zululand, July 22nd, 1879.

\section{HARVEY'S REMAINS}

\section{To the Editor of THE LANCET.}

SIR,-As nothing has been done since Dr. Richardson wrote his interesting paper a year ago, I venture to trouble you with this letter. I paid a visit to the Harvey vault in Hempstead Church on August 26th, and was amply repaid for my trouble. The church is worth a visit, and the drive from Saffron Walden is very pretty. Something should be done at once to preserve the remains from further decay, and if they cannot be transferred to Westminster I think at any rate they might be put into another lead coffin and removed to another portion of the vanlt where the wet cannot reach and stones be thrown. The expense of this would be trifling, providing the consent of the family can be obtained. It appears there are only female descendants of the family left, and this may account for the state of the vault; the bars of the windows want repairing, and some close wire netting placed to prevent stones and dirt getting in.

To restore the church would cost a great deal, although the building is well worth it; it can be seen for some miles, 